\title{
History of Territorial Development and Formation of Urban Landscape in the South of Russia
}

\author{
Aleksandra Vorobyeva ${ }^{1, *}$ \\ ${ }^{1}$ Don State Technical University, pl. Gagarina, 1, Rostov-on-Don, 344010, Russia
}

\begin{abstract}
The article deals with the problem of historical transformation of natural landscape as a result of urban development of territories. We identified historical processes of natural landscape transformation from the beginning of its urban development till the formation of modern cityscapes. Distinctive characteristics and peculiarities of natural landscape were defined. We distinguished main types of landscape (flat, piedmont and mountain landscapes). Time periods of the development of city territories of the region with various landscape conditions and main stages of historical development of these territories are considered, as well as historical features of their development, temporal processes of complication of interrelations of various factors and characteristics of urban environment, and other problems of human activity influence on city landscape components, including the impact on the ecological state of the region.
\end{abstract}

\section{Introduction}

In recent years more and more attention of experts is given to problems of studying of modern urban landscape condition, regularities and methods of their transformation while deciding the environmental problems arising in the course of creation of new urbanized territories and reconstruction of the existing ones. The first definitions of the concept "landscape" was made by geographers in the end of 19th and the beginning of the 20th centuries. In the course of increasing of scientific knowledge the concept "landscape" indicated the process of interrelation of natural components: geological structure of the area, its relief, vegetation, soil, water relationships and climate. Transformation of a natural landscape by humans in the course of their activity has led to developing of whole new territorial complexes. A city landscape is one of the most important components characterizing the condition of a modern habitat. Researchers have shown that problems of landscape formation of the southern Russian cities are of particular importance, because many of those cities are resorts or have balneological potential. They have the higher standards of the habitat organization and comfort level, a larger scale of natural landscape transformation and higher level of recreational development that can provide not only

\footnotetext{
*Corresponding author: rostland@mail.ru
} 
restoration of physical and spiritual powers of people, but also satisfaction of a wide range of their requirements [1-5].

\section{Methods and Results}

Climatic conditions of the Southern Russian region appeared under the influence of the Black, Azov and Caspian seas, the mountain system of Greater Caucasus and the southern part of East European Plain. The territory is characterized by a big variety of landscapes flat, foothill and mountain. The flat steppe landscapes prevailing in the region are developed, plowed and built up. Virgin sites on black soils with a silvery feather grass have remained only on reserved sites or at forest belts on suburbs of settlements. Along water areas there are natural and artificial woods which are placed unevenly across the territory. The foothills of Greater Caucasus are presented by terrace-like inclined plains. There is steppe vegetation on salty soils of a flat part of the territory. Slopes are covered with broadleaved oak and hornbeam woods which are replaced with meadow steppes. Heightdepending change of natural landscapes is characteristic of mountainous areas. The broadleaved woods are replaced by coniferous forests of firs, spruces and pines; subalpine meadows with rosebay elfin woods; higher there are the Alpine motley grass meadows.

North Caucasus region is located between moderate and subtropical climatic zones. The mountain system of Greater Caucasus is a border between them and complicates the transfer of cold air masses. The warm climate, various and dense vegetation, unique landscapes and mineral springs, sandy and pebble beach's of rivers and seas have made the region one of the largest areas for resort treatment, rest and tourism in Russia. There are four recreational areas on this territory: Caucasian and Black Sea, North Caucasian, Mountain-Caucasian and Caspian.

As evidenced by historical experience, the beginning of landscape development and transformation in the region was followed first of all by impact on biological component part of a landscape. The comparative analysis of characteristics of development of the ancient cities and cities which were developed during the Soviet period shows that irrespective of time and the reasons of origin there are certain regularities of development and functional use of the territories due to natural features of the area. So, ancient settlements and trading posts located on the Caucasian Black Sea coast, such as Dioscuria, Pityus, Phasis (VIII-VII centuries BC) settlements had focal character. Lifted over the boggy territory, they were placed at beds of the mountain rivers, had convenient harbors, distinctly southern orientation. The cities extended along the coastline and were sea-facing, using beneficial effect of weak sea breezes, typical for the coast. Searches of new lands, military conquering of sales markets determined a new wave of colonization of the coast by the Romans, and later by the Byzantines. Ancient settlements grew and gradually joined together to small towns with more extended outlines. The building of religious constructions, temples and monasteries began in picturesque places of mountains and in the best places of a relief.

Great geographical discoveries in the 15 th century led to change of sea routes and the center of trade moved to the northern Black Sea Coast. That is why development of cities suspended for a long time. Natural landscape remained on the most part of the coast. When the Caucasus was joined to Russia in the 19th century the new stage of development of the coast began. Drainage of swamps, construction of the railroad from Novorossiysk to Batumi along the Black Sea coast, enhancement of the military equipment that depreciated the role of a relief for defense promoted development of the coastal territories. The cities purchased linear structures, the city centers were allocated. Shore outlines changed, the "secondary" nature appeared. Former boggy territories were forested. The first recreational facilities appeared. 
During the Soviet period active development of resorts began. The functional and planning organization of the territories in the first general urban plans of resorts considered their recreational nature. Accurate allocation of resort, residential, municipal and warehouse zones was carried out on the basis of the environmental analysis. According to the master plan of Sochi - Matsesta resort (1936) the highway separates public coastal parks from the sanatorium-resort zone located on the slopes. Building area for the resort territories was rather small The residential territories were built up with 2-3-storey buildings.

The cities of Caucasian Mineral Waters region began to develop intensively in the Soviet period, though this area was acknowledged by medical board as a resort in 1803.After laying the Vladikavkaz railroad in 1875 the resort began to develop rapidly, the first hotels, new hydropathics and mud baths appeared. Development of a natural landscape was inconsiderable. Resorts were built up with comfortable dachas located in country areas: in Kislovodsk - Rebrovayabalka; in Pyatigorsk - the Proval; in Zheleznovolsk - a foot of the slope of the mount Zheleznaya. Unique natural features of the area and new approaches in design allowed to create in these cities the unique resort parks with medical functions. The spatial organization of resort parks was created taking into account the interaction of the material park environment and medical processes happening on their territories. For example, the resort park of Kislovodsk founded in 1820-s along the river Olkhovka on slopes of the Dzhinalsky ridge. It is situated 800-1300 m above sea level. By the end of the XX century it was the largest park in Europe (the total area of the park is 1380 hectares), the second was Richmond park in London (955 hectares.). For the first time in Russia the relief of territories in the Kislovodsk park was used for allocating of six terrenkurs from 1700 to $6000 \mathrm{~m}$ long which allowed to use the territory of the park for treatment of heart and vascular diseases by dosed (in time and speed) walks in mountains according to a method of the German doctor M. Ertel. Total length of the paths of terrainkur marked with red sand is more than 30 kilometers. There are sign plates every 100 meters along a route with the indication of the route, height above sea level, the steepness of ascent and descent that allows the guests to adjust the physical effort. The walk begins from the Lower park, along the main avenue with parterres, to a flower calendar, further on the bridge across the Olkhovka river to the Mirror pond and further through the dolomite rocks to the Ladies Whim bridge across the small river, up the mount Sosnovayato the valley of roses (fig. 1).

\section{Kislovodsk Resort Park}

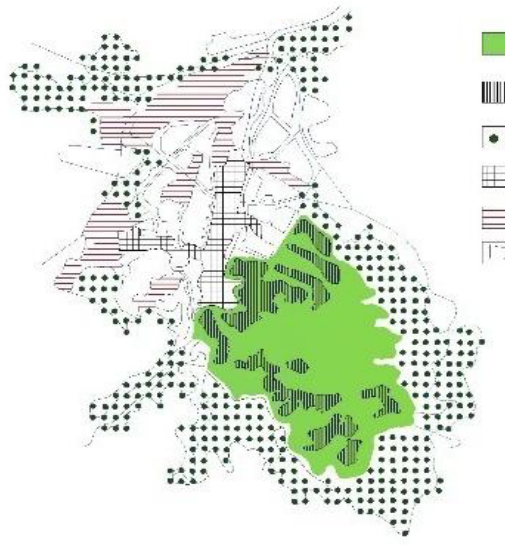

\section{Resort Park}

|||||||||| Resort complexes

- Forest parks

Harden squares and boulevards in the city center Public gardens and boulevards

City districts

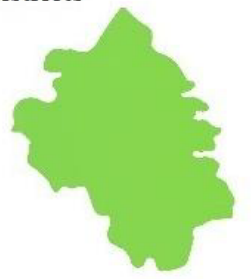

Fig. 1 The layout plan of the resort park in the structure of Kislovodsk urban area 
Natural beauty of the landscape was emphasized during creation of the resort park in the city of Pyatigorsk. It appeared in 1835 when a garden school (or the State garden) was founded on the area of four dessiatinas. By 1912 it reminded an old-time manor park. AS far as the city grew, the park was renamed the Resort park named after Karl Liebknecht. The artificial lake appeare dint he park.

\section{Pyatigorsk Resort Park}
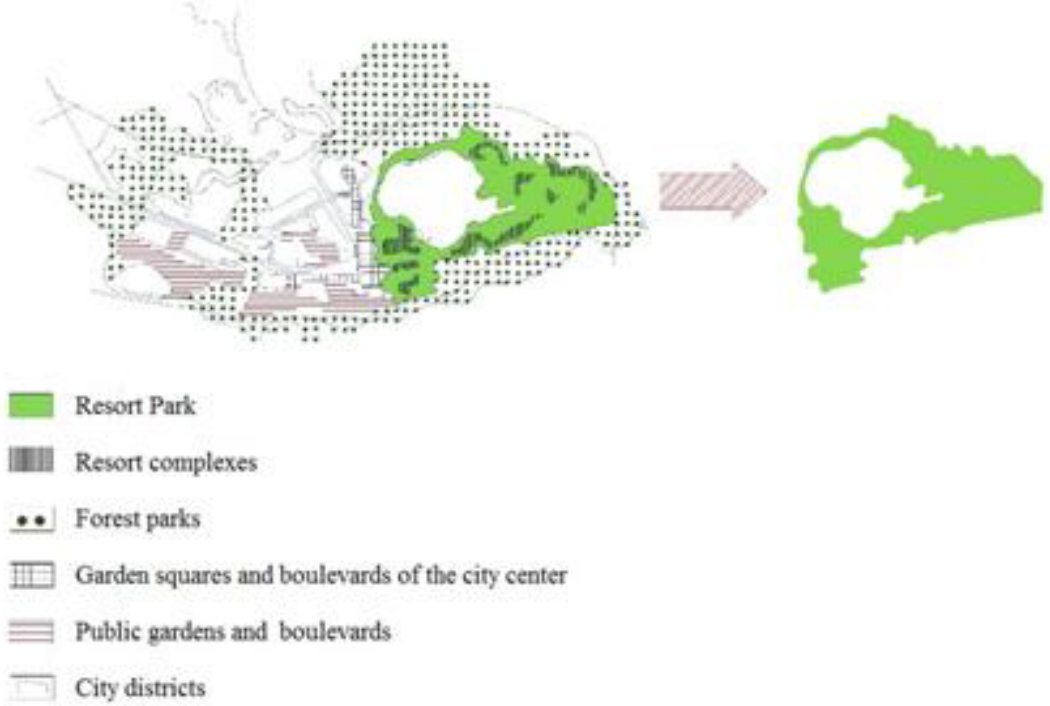

Fig. 2 The layout plan of the resort park in the structure of Pyatigorsk urban area

The natural Zheleznovodsk valley overgrown with the dense broad-leaved wood reminds a dark green surface of the sea with dome-shaped and steep islands. In 1825 the medical park was set up on a slope of the mountain Zheleznaya and the first forest clearing opened the way to new mineral springs. According to the first plan of reorganization of Zheleznovodsk resort territory, only rich people could build new houses.

The Mountain-Caucasian recreational zone covers an axial part of the main ridge of Greater Caucasus. Nowadays there are small mountain resorts in Dombai on the territory of the Sheberdinsky reserve, in the Prielbrusye area - at the settlements of Terskaya, Elbrus,Tegenekli and others. The Caspian recreational area is extended along the coast of the Caspian Sea. It has good sandy beaches and its natural landscape is not well-developed.

On the territories of large recreational zones of the North Caucasus there is a violation of balance between intensity of human intervention in the environment and a natural capability to recovery. So, environmental concerns take place. There is spontaneous development of a foothill zone for different purposes in large resort cities that causes a striped pattern of urban areas, separation of the residential and resort territories by transit highways; pedestrian ways are combined with congested transport routes or have chaotic nature that reduces their recreational and functional use.

A new geopolitical situation strongly limited the use by residents of Russia of traditional vacation spots in the Crimea, Transcaucasia and the Baltic states. The direction of recreational flows changed. That requires a special attention to arrangement, protection and recovery of the environment of the oldest resort area in the South of Russia. Potentially it can be used much more effectively, and the condition of a landscape of the territory 
doesn't meet the requirements that would provide complete recovery of physical and spiritual power of the population.

Other cities of the researched region also have difficult city-planning, landscape and ecological situation because interests of industrial production and territorial interests of the cities not always coincided. Their limited resources and priority of the current tasks over perspective problems led to decisions that are non-optimal for the functional planning and landscape organization of the cities. Evolution of landscape development of the territories shows specific tendencies in development of urban areas in steppe zone. Before the period of industrial development (late 19th century) the spatial and planning organization of the cities largely depended on environmental conditions, being subject to the landscape and hydrographic conditions of the territory. Later (since the end of the 19th century) development of road and transport network determined the arrangement of urban areas. Once being an important landscape factor, waterways gradually lose their value as transport arteries. Changes in social and economic development produce a qualitative shift in both planning structure and pace of territorial development and as a result - in the ecological condition of the cities. For example, Rostov-on-Don is one of the largest industrial cities of North Caucasus region where all features of natural landscape development and consequences of transformation processes are shown. The city appeared at the beginning of XVIII century as a trade post on the frontier passing across the southern bank of the river Don. The advantageous geographical location and the historical past determined both cityforming(trade, transport) and strategic functions. In 1761 the fortress called by the name of Dimitry of Rostov was constructed to protect the frontiers and the Temernitsky port. In 1797 the first city plan was approved as well the city plan of Nakhichevan. The territories, which were the most suitable for construction, were being developed. Ravines and streams remained untouched and constituted a natural framework of settlements.

Further development of the cities was linear and took place along an important landscape axis - the river Don. First of all sites with a calm relief between the Don and the Temernik rivers, Generalnaya, Kamyshevakha and Kiziterinka ravines were used. The housing development in Dolomanovskaya and Soldatskaya settlements extended. Small settlements had no industry and had no significant effect on a landscape and ecological condition of the territory. The natural framework wasn't broken yet. Gradual growth of the city, development of the industry and transport made let overcome a natural barrier. On the map of 1811 Rostov-on-Don occupies the territory on the right bank of the Don up to present Bolshaya Sadovaya Street which was a northern border of the city.

After liquidation of the fortress in 1835 and till the 1930s nothing interfered with development of building in a latitudinal direction. A continuous front of building along the river Don was organized. Construction of the railroad determined rapid development of a suburban framework of the territories. A settlement named Lengorodok appeared across the Temernikriver. Along the railroad there were small industrial enterprises and warehouses.

The industrialization of the country which began in the 1930s demanded new extensive territories for construction of the plants and working settlements. Rostov-on-Don became large trade city and the major port in the south of Russia. The industrial and warehouse areas placed haphazardly began to affect the ecological condition of residential districts. The merge of Rostov-on-Don and Nakhichevan increased the city territory almost twice. The adverse factors also amplified because, from now on, industrial enterprises were in a dwelling area. Owing to the town-planning theories dominating at that time, and also due to the lack of the developed infrastructure workers settlements were built near a plant. The territories along the river Temernik and Kiziterinovskaya and Bezimyannaya ravines were allocated for building. It destroyed their natural framework, interfered with free aeration of the deep built-up sites, and worsened the ecological situation. 
The master plans developed for Rostov-on-Don $(1929,1945,1971)$ assumed building regulation, accurate functional zoning of the territory; organization of a green zone in a North East suburb to protect the city against dust storms; city development in the western and northern directions; development of a left bank of the Don and the green island as a recreation area, planting green spaces around the city, etc. Many of project offers remained a dead letter. Now the natural framework of the city is broken and there is a difficult ecological situation which is determined by a number of mistakes including town-planning ones.

In spite of the fact that in recent years the process of urbanization was considerably slowed down all over the country, in the North Caucasus region population growth is observed through migration of displaced persons, families of the demobilized members of the armed forces and migrants from the north of Russia. The area has become a border territory and consequently, there will be problems with further development and expansion of residential locations, landscape transformations and sanitary and hygienic condition of the territories. The most important sources of pollution in the region are industrial and agricultural enterprises transport. Many settlements have unacceptably high level of ground waters and are in dire need of collector and drainage networks. At the same time there is a strong pollution of the cities with solid domestic waste. The quantity of small dumps, car washes, car repair shops which aren't shown on the ecological maps of the cities increases. The decrease in industrial pollution of the cities observed in recent years is caused by the fact that almost all industrial enterprises are idle. Such situation causes reduction of concentration of metals and other elements in atmospheric precipitation, decrease of pollutants in water systems and concentration of heavy metals in the top soil.

\section{Discussion}

As the research shows, historical conditions of human impact on the environment of the southern region were the main reasons for artificial formation of urban landscapes and radically changed its natural character. Draining wetlands on the Black Sea coast, deforestation in coastal and a foothill territories, dense building on flat sites of the territories have created a "secondary" nature and modern city landscapes. City landscape facilities, as well as its general landscape structure are the main ecological regulators which are most effective for preservation of the healthy habitat.

\section{Conclusions}

The analysis of city landscapes located in flat and mountainous areas has shown historically established distinctions in the way of their formation, spatial and planning heterogeneity. Urban areas development and building-up without regard to climatic and orographical conditions has led to the negative phenomena which influence the organization and condition of landscape of the existing southern cities.

Development of urban areas on sites with a natural landscape most convenient for building resulted in overcrowding, reduction of territories with a valuable natural landscape, striped pattern of urban areas, violation of green areas balance. All this has considerably lowered the quality of life in the urban territories in the South of Russia.

The comparative analysis of characteristics of development of the ancient, old cities and cities which were developed during the Soviet period shows that irrespective of time and the reasons of their origin, the territories have certain regularities of development and functional use due to natural features of the area. 
Each city is unique and peculiar. Creating favorable living conditions and preserving ecological balance in case of reconstruction and a construction in urban areas of the southern region is impossible without development of scientifically based data bank for recovery of the ecological framework and transformation of existing natural landscape of the territories.

\section{References}

1. A.M.Vorobeva, Tasting the landscape, 53 ifla world congress, Torino, Italy, 350 (2016),

2. A.M.Vorobeva, S.L.Glebova, SPbSFTU of Saint-Petersburg Swedish University of Agricultural Sciences, Sweden Uppsala, Sweden, 66-67 (2016)

3. R. Alihodzic, V. Murgul, N. Vatin, Applied Mechanics and Materials, 680, 494-498 (2014)

4. G.Radovic,V. Murgul, N. Vatin, Applied Mechanics and Materials, 641-642, 634638 (2014) DOI: 10.4028/www.scientific.net/AMM.641-642.634

5. I. Yamshanov, V. Goryunov, V. Murgul, Procedia Engineering, 117, 675-684 (2015) 